\title{
Performance and carcass traits of heifers Rubia Gallega $x$ Nellore supplemented with chromium picolinate
}

\author{
Paulo Sergio Andrade Moreira'* , Aymann El Farra², Leonardo Virgilio Gregorio Guimarães³, Fabio José
} Lorenço ${ }^{4}$, Angelo Polizel Neto', Celina Palhari ${ }^{5}$, Rodolfo Cassimiro Araujo Berber ${ }^{6}$

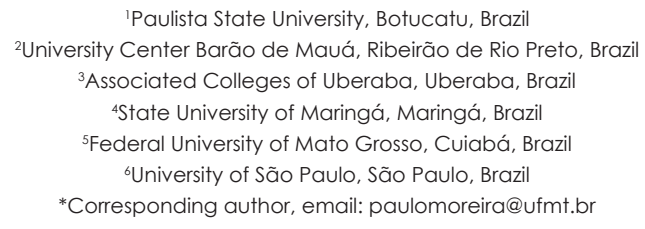

\begin{abstract}
The objective was to evaluate the productive performance and the carcass traits of Nellore (NEL) and Rubia Gallega x Nellore Fl (NRG) heifers, subjected to energy-protein supplementation with chromium picolinate (CrP). Sixty heifers ( $30 \mathrm{NEL}$ and $30 \mathrm{NRG}$ ) with a mean initial adjusted body weight (BW) of $214.50 \mathrm{~kg}$ and mean age of 201 days were distributed into a completely randomized design, in a $2 \times 2$ factorial (2 genetic groups $\times 2$ supplementation groups). The experimental period lasted 320 days. There was no interaction ( $p>0.05$ ) between the genetic groups and the supplements. The addition of CrP to the supplement did not alter the performance and carcass characteristics evaluated $(p>0.05)$. However, the NRG genetic group was better than the NEL in the performance characteristics as final live weight, mean daily gain and carcass yield as carcass yield, Muscularity $(p \leq 0.05)$. The use of the Rubia Gallega genotype in crossbreeding provides an increase in production of heavier carcasses with lower fat percentages and higher yields when compared to the use of Nellore heifers.
\end{abstract}

Keywords: crossbreed, mineral, muscle growth, ultrasound

\section{Introduction}

Brazil has climatic conditions and territorial extension to favor livestock farming in a pasture system (Ferraz \& Felício, 2010).

However, this production system based on the constant and prolonged extraction of natural resources, associated with the seasonality of forages, can negatively influence productivity rates (Santos et al., 2009; Moreira et al., 2012). The slaughtering of females may be an alternative to the Brazilian consumer market, however, the price paid by the slaughterhouses to the females carcass is normally $10 \%$ lower than males. (Missio et al., 2013)

Anotheralternativeis thesupplementation associated with grazing to improve carcass quality, promoting better results (Taveira et al., 2014).

Chromium $(\mathrm{Cr})$ stands out among microelements of importance to animals. Cr acts indirectly on energy metabolism through the formation of the so-called Glucose Tolerance Factor, increasing the sensitivity of cells to insulin, and consequently optimizing the use of glucose (Ewelina \& Krejpcio, 2010; Spears \& Weiss, 2014). As it participates in energy metabolism, it is assumed that $\mathrm{Cr}$ may influence in the quality of the carcass of the animals (Polizel Neto et al., 2009a), which resulted in research focusing on the supplementation of cattle (Domínguez-Vara 
et al., 2009; Kneeskern et al., 2016; Oliveira et al., 2016).

On the other hand, it is necessary to know the potentialities and limitations of the different breeds of cattle and the search for genotypes adapted to our climate conditions, which associate this with the productive characteristics similar to that of European animals (Lopes et al., 2008; Marques et al., 2012). Thus, it was observed that the Rubia Gallega x Nellore crossbreed has shown potential of use in tropical conditions, presenting a high rate of muscle growth and weight gain, besides providing carcasses with high commercial yield (Sanchez et al., 2005; Taveira et al., 2014).

This work aimed to evaluate the effect of supplementation with chromium picolinate on the productive performance and carcass characteristics of Nellore and F1 Rubia Gallega $x$ Nellore heifers raised to pasture.

\section{Materials and methods}

The experiment was carried out at the Calixbento farm, located in Nova Canaã do Norte (10 ${ }^{\circ} 50^{\prime} 15.65$ "S and $55^{\circ} 40^{\prime} 37.29^{\prime \prime}$ W), in the northern region of the state of Mato Grosso, Brazil. All procedures were approved by the ethics in animal experiments from the Federal University of Mato Grosso, number 410/2014.

Sixty heifers, 30 Nellore (NEL) and $30 \mathrm{Fl}$ Rubea Gallega x Nellore (RGN) heifers, with initial age of 210 days, individually identified, were used. From each genetic group, 15 animals received energetic-protein supplementation plus chromium picolinate (CrP) and 15 received protein-energy supplementation without $\mathrm{CrP}$ (control). The animals were randomly distributed in a $2 \times 2$ factorial scheme, being: two genetic groups (NEL and RGN) and two supplements (containing or not $\mathrm{CrP}$ ). The animals were kept in pastures of Brachiaria brizantha cv. Marandu (two pickets of 24 hectares / each), provided with drinkers and feeders with nine meters in length in each picket, to supply the supplements. The experiment was conducted in an experimental phase with a duration of 320 days. However, measurements of performance and tissue growth parameters were performed at two different times: at 420 days ( 14 months) corresponding to the dry season (April-October) and to 510 days (17 months), corresponding to the rainy season (November-March).

In the dry period, the consumption of the supplement, containing $16 \%$ of crude protein associated or not of $1.00 \mathrm{mg}$ of $\mathrm{CrP} / \mathrm{kg}$ of supplement, was $0.2 \%$ of body weight. In the water period, supplement use, containing $20 \%$ crude protein, was $0.5 \%$ of body weight, added or not of $0.5 \mathrm{mg}$ CrP / $\mathrm{kg}$ supplement.

For the performance evaluation, the animals $(n=60)$ had their initial mean body weight adjusted by covariate to $214.5 \mathrm{~kg}$ and weighed every 28 days. Before each weighing, in individual weighing scales with a capacity of $1000 \mathrm{~kg}$, the animals were fasted for 12 hours, thus determining the final body weight (FBW), total body weight gain (TBWG), average daily gain (ADG) and percentage of weight gain (\% WG).

Ultrasonographic exams of the animals ( $n=60)$ at 14 months and 17 months of age were performed by ultrasound images of the loin eye area $\left(\right.$ LEA-cm ${ }^{2}$ ) and subcutaneous fat thickness (SFT-mm). The images were obtained between the 12th and 13th ribs, transversal to the Musculus Longissimus thoracis, with the SFT being measured in the lateral middle third of the LEA. The examinations were performed with PIE MEDICAL - Scanner 200 veterinary ultrasound, with a sector curved array scanner probe, model 51B04UM02.

Bone tissue growth was assessed by measuring the perimeter of the medial portion of the left metatarsal bone (PS-cm) using a PVC tape measure from 0 to $100 \mathrm{~cm}$.

Twenty-eight heifers of heifers were evaluated, being 14 NEL (7 CrP and 7 Control) and 14 RGN (7 CrP and 7 Control), with average body weight above $350 \mathrm{~kg}$.

The heifers were pre-weighed on the day before slaughter, thus obtaining the slaughter body weight (BWFC), and slaughtered in a commercial refrigerator under Federal Inspection Service, following the normal flow of the industry.

In the hot carcass, the subjective visual evaluation of conformation / muscularity (CONF) and fat / finishing coverage (FIN) was carried out, and at the end of the slaughter line the warm carcass weighing (WCW) was performed. 
For the conformation of the carcass, the muscular coverage of the hindquarters was evaluated and the scores from 1 to 5 were: concave (1), sub-rectilinear (2), rectilinear (3), sub-convex (4) and convex (5).

For the evaluation of finishing, the amount of fat in the carcass was visually estimated, and scores were also assigned from 1 to 5 : without fat or lean (1), fat with 1 to $3 \mathrm{~mm}(2)$, fat with 3 to 6 $\mathrm{mm} \mathrm{3}$ ), fat with 6 to $10 \mathrm{~mm}(4)$ and fat greater than $10 \mathrm{~mm}(5)$.

In order to evaluate the warm carcass yield (WCY, in\%), the warm carcass weight (WCW, in $\mathrm{kg}$ ) at the end of the slaughter line, divided by the slaughter body weight of the fasting cattle (BWFC, in kg), taken on the day before slaughter (WCW / BWFC*100). Statistical analyzes were performed using the SAS program (2009). The mixed model was used as fixed effects of genetic group, of CrP and its interaction, adopting 0.05 of probability for the error type 1:

$$
\text { Yijk }=u+G G j+G G j \times C r k+e i j k
$$

being:

$\mathrm{Y}=$ observed value of animal i ( 1 to 60 ) for genetic group j (1 and 2), supplement with $\mathrm{Cr}$ (1 and 2); $u=$ general average;

$G G j=$ fixed effect of the genetic group (1 and 2); Crk = effect of CrP use (1 and 2);

GGj'Crk = interaction effect between $G G$ and $\mathrm{Cr}$;

Eijk = random error associated with each observation $(0 ; 1)$.

\section{Results and discussion}

There was no interaction effect $(P>0.05)$, between the supplements and the genetic groups NEL and RGN, from weaning to slaughter, for the evaluated variables.

The supplement containing CrP did not influence the performance of the heifers (Table 1), corroborating with Swanson et al. (2000) who also did not observe effect of yeast $\mathrm{Cr}$ supplementation for six weeks on daily weight gain and gain efficiency in growing heifers.

Table 1. Performance evaluation of Nellore and Fl Rubia Gallega x Nellore heifers supplemented with $\mathrm{Cr}$, from weaning to slaughter

\begin{tabular}{|c|c|c|c|c|c|c|c|}
\hline \multirow{2}{*}{ Variable } & \multicolumn{2}{|c|}{ Supplementation } & \multicolumn{2}{|c|}{ Genetic group } & \multicolumn{3}{|c|}{$P$} \\
\hline & Chromium & Control & NEL & RGN & Chromium & GG & $\mathrm{Cr}^{*} \mathrm{GG}$ \\
\hline ILW * $(k g)$ & $214.5 \pm 0,0$ & $214.5 \pm 0,0$ & $214.5 \pm 0,0$ & $214.5 \pm 0,0$ & - & - & - \\
\hline FLW (kg) & $366,9 \pm 3,2$ & $365,7 \pm 3,3$ & $353,9 \pm 3,9$ & $378,7 \pm 4,0$ & 0.792 & $<0,001$ & 0.244 \\
\hline TWG (kg) & $152,4 \pm 3,3$ & $151,1 \pm 3,2$ & $139,4 \pm 3,9$ & $164,1 \pm 4,0$ & 0.792 & $<0,001$ & 0.244 \\
\hline ADG $(\mathrm{kg})$ & $0.476 \pm 0,0$ & $0.472 \pm 0,0$ & $0.435 \pm 0,0$ & $0.512 \pm 0,0$ & 0.792 & $<0,001$ & 0.244 \\
\hline$\% W G$ & $71,6 \pm 1,6$ & $70,7 \pm 1,5$ & $65,2 \pm 1,9$ & $77,0 \pm 1,9$ & 0.672 & $<0,001$ & 0.351 \\
\hline
\end{tabular}

Similarly, Zanetti et al. (2003) reported that there was no difference in weight gain, efficiency and feed conversion using supplementation with $0.4 \mathrm{mg} / \mathrm{kg}$ dry matter (DM) Cr complexed to the organic molecule in Holstein calves not exposed to stress. On the other hand, Bernhard et al. (2012) reported that $\mathrm{Cr}$ supplementation for the basal diet may have beneficial effects on the performance and health of crossbred newborn calves.

Productive performance, especially in parameters related to weight gain, is frequently evaluated in animals supplemented with $\mathrm{Cr}$ (Domínguez-Vara et al., 2009; Montemór \& Marçal, 2009), but the results are varied. In animals submitted to low stress, most studies found in the literature did not observe Cr effects on these variables (Swanson et al., 2000; Zanetti et al., 2003; Montemór \& Marçal, 2009; Oliveira et al., 2016). Under comfort conditions, Cr levels in the diet meet the requirements for the normal development of the animal (Zanetti et al., 2003).

The best productive performance of $\mathrm{Cr}$ supplemented animals under stress conditions may be related to a drop in cortisol-mediated immune resistance, compromising homeostasis. Therefore, $\mathrm{Cr}$ supplementation would minimize these changes (Grasso et al., 2001). Stressmodulated cortisol mobilizes amino acids in extrahepatic tissues, especially in muscles, increasing the amount of enzymes needed to convert amino acids to glucose, increasing the absorption of glucose by the cells, reducing the body's protein reserves, decreasing the rate 
of protein synthesis, which results in intracellular protein catabolism (Ottersbach et al., 2008).

Regarding the genetic groups, there was a difference ( $p<0.05$ ) in FLW, in which RGN animals weighed $378.7 \mathrm{~kg}$ and NEL animals weighed $353.9 \mathrm{~kg}$, a difference of $24.8 \mathrm{~kg}$. Total GP was also influenced by the genetic factor $(p \leq 0,001)$. RGN animals presented gains of 164.1 $\mathrm{kg}$ at the end of the experiment and the NEL animals obtained gains of $139.4 \mathrm{~kg}$ (RGN gained $24.7 \mathrm{~kg}$ more than NEL), there being synergy between the results, since both involve weight development.

Our performance results are partially explained by the higher intake of dry matter (DM) by animals with taurine genetics (Bos Taurus taurus), which present greater capacity of the digestive tract (Kuss et al., 2007; Menezes et al., 2007). This fact was previously evidenced by Menezes \& Restle (2005) in a study with cattle of different degrees of Zebu (Nellore) and Taurine (Charolais) blood. These authors observed lower weight gain of zebu animals (Bos Taurus indicus), due to the lower capacity of food intake by these animals.

Similar to previous results, the ADG of the RGN animals was higher than that of the NEL animals. The gains were 0.512 and 0.435 $\mathrm{kg}$, respectively, differing by $0.07 \mathrm{~kg}$. This result is similar to that reported by Taveira et al. (2014) studying Nellore males and mestizos of Rubia Gallega $x$ Nellore. These authors found greater average daily weight gain and mean final weight of the crossbred animals when compared to pure Nellore, evidencing the superiority of the Rubia Gallega genotype as a factor that improves the productive aspects linked to the weight gain. However, it should be emphasized that the different performances among the races may be partially related to the selection for weight gain that the genetic groups, or herds within the breed, received in the previous generations (Climaco et al., 2011).

The percentage of GT was also significantly higher in the RGN animals, whose values were $77 \%$. On the other hand, the NEL animals had $65.2 \%$ of GT, the difference between the genotypes being $11.8 \%$. Thus, this result suggests that this variable was influenced by other performance parameters. The animals that presented the highest ADG, FLW and WG obtained, consequently, a higher WG rate.

In the growth the body mass increases as a function of time, with the deposition of proteins, fat and minerals (Owens et al., 1995), thus, the above results demonstrated the superiority of RGN animals in all productive aspects related to weight gain. This finding was expected, since the Rubia Gallega genotype shows high growth rates and superior performance, even in its crosses, when compared to pure Nellore animals (Sanchez et al., 2005; Taveira et al., 2014).

According to the literature, the cross between bull and zebu genotypes tends to promote superiority for performance characteristics, especially for the greater muscular growth, when comparing to the pure Zebu genotype, through the heterosis gain (Bianchini et al., 2008; Climaco et al., 2011).

Supplementation with $\mathrm{CrP}$ did not change the carcass characteristics BWFC, WCW, WHR, CONF, and FIN in relation to the control group (Table 2) ( $p>0.05)$. These findings suggest similarity between the values of productive performance presented (ADG, total WG and FLW) due to the types of supplements.

Table 2. Means of carcass characteristics of Nellore and Fl Rubella $x$ Nellore heifers supplemented with $\mathrm{Cr}$

\begin{tabular}{|c|c|c|c|c|c|c|c|c|}
\hline \multirow{2}{*}{ Variables } & \multicolumn{2}{|c|}{ Supplementation } & \multicolumn{2}{|c|}{ Genetic group } & \multirow[b]{2}{*}{ EPM } & \multicolumn{3}{|c|}{$P$} \\
\hline & Chromium & Control & NEL & RGN & & Supplem & GG & $\mathrm{Cr}^{\times} \mathrm{GG}$ \\
\hline BWFC (kg) & 378,2 & 372,3 & 357,3 & 393,1 & 6,5 & 0,392 & $<0,001$ & 0,930 \\
\hline WCW $(\mathrm{kg})$ & 203,1 & 201,8 & 190,65 & 214,2 & 4,1 & 0,738 & $<0,001$ & 0,750 \\
\hline WCY (\%) & 53,6 & 54,1 & 53,3 & 54,4 & 0,4 & 0,255 & $<0,001$ & 0,343 \\
\hline CONF (1-5) & 3,4 & 3,3 & 3,0 & 3,6 & 0,1 & 0,324 & $<0,001$ & 0,971 \\
\hline FIN (1-5) & 2,9 & 3,0 & 3,2 & 2,6 & 0,1 & 0,573 & $<0,001$ & 0,573 \\
\hline
\end{tabular}

group, BWFC: Body weight of slaughter, WCW: Hot carcass weight, WHR: Hot carcass yield, CONF: Conformation - Muscle rate, FIN: Finish of carcass fat.

These results differ from those found

by Polizel Neto et al. (2009a), These authors evaluated the supplementation of $2 \mathrm{mg} \mathrm{Cr} /$ animal/day in performance and carcass 
characteristics of Nellore and Fl Brangus $x$ Nellore grazing cattle, and found higher values of WCW and WHR in carcasses from supplemented animals. Moreira et al. (2012), also different from our results, reported a difference of WCW and WHR in Nellore steers supplemented with $\mathrm{Cr}$ chelate under grazing regime. Possibly the animals of the present experiment had sufficient comfort that $\mathrm{Cr}$ supplementation did not show influence on the physiological responses of the animals.

There was a difference ( $p<0.05$ ) between NEL and RGN heifers for all variables related to carcass characteristics: BWFC, WCW, WHR, CONF and FIN.

RGN increased $38.5 \mathrm{~kg}$ in BWFC more than NEL ( $p<0.001$ ), this difference was extended to WCW, with RGN heifers presenting an increase of $23.55 \mathrm{~kg}$ compared to NEL $(p<0,001)$.

In WCY, RGN increased $1.1 \%$ more than NEL ( $p<0.001$ ), suggesting that the Rubia Gallega breed has a high growth rate and low fat deposition in the carcass (Varela et al., 2004; Oliete etal. 2006). Fat tends to dilute the proportion of muscles in the carcass and when their excess is eliminated, the carcass weight is also reduced in relation to the slaughter weight, consequently decreasing the yield. Thus, a greater muscle / fat ratio is expected to increase WCY. This result is similar to that obtained by Taveira et al. (2014), which recorded for animals Rubia Gallega $x$ Nellore a carcass yield $1.22 \%$ higher than pure Nellore, and was lower than reported by Sanchez et al. (2005), that in experiment with males Rubia
Gallega x Nellore vs. Nellore slaughtered at 22 months, found that carcass yield values were $2.69 \%$ higher in crossbred animals.

The results of WCW and WCY verified the potential of the Rubia Gallega breed for the production of heavier and better yielding carcases, which is economically desirable. The importance of carcass yield in Brazilian systems is a consequence of the commercialization method, which remunerates the producer according to the warm carcass weight (Lopes et al., 2012).

Some studies have shown that the zebu genotype provides a higher WCY than the taurine because it is associated with lower weights of gastrointestinal content and viscera (Rubiano et al., 2009). However, the zebu genotype showed a marked additive effect to this characteristic (Rubiano et al., 2009), which may have influenced the reduction of the difference between the genotypes for this variable, since pure taurine animals were not used.

RGN heifers at 14 months presented higher LEA than NEL heifers ( $p=0.003$ ), with values of 43.7 and $32.6 \mathrm{~cm}$, respectively. These findings suggest higher precocity of taurine regarding the muscularity (Lopes et al., 2008).

This difference did not occur at 17 months, when the animals presented statistically similar results ( $p>0.05$ ), demonstrating the potential of RGN animals for early muscle growth in the rearing phase, which corresponds physiologically to the phase of rapid muscle growth. Therefore, as the animal approaches its adult weight (weight at maturity), protein deposition decreases (Owens

Table 3. Tissue growth means (muscle, adipose and bone) of Nellore and F1 Rubia Gallega x Nellore heifers supplemented with chromium

\begin{tabular}{|c|c|c|c|c|c|c|c|c|}
\hline \multirow{2}{*}{ Variable } & \multicolumn{2}{|c|}{ Supplementation } & \multicolumn{2}{|c|}{ Genetic group } & \multirow{2}{*}{ EPM } & \multicolumn{3}{|c|}{$P$} \\
\hline & Cromo & Control & NEL & RGN & & Supplem & GG & $\mathrm{Cr}^{\times} \mathrm{GG}$ \\
\hline \multicolumn{9}{|l|}{ LEA (cm) } \\
\hline $14 \mathrm{mo}$ & 35,7 & 40,6 & 32,6 & 43,7 & 3,6 & 0,191 & 0,003 & 0,320 \\
\hline $17 \mathrm{mo}$ & 45 & 45,2 & 45,3 & 44,9 & 1,8 & 0,882 & 0,794 & 0,235 \\
\hline \multicolumn{9}{|l|}{ SFT (mm) } \\
\hline $14 \mathrm{mo}$ & 2,1 & 1,6 & 1,7 & 2 & 0,26 & 0,030 & 0,432 & 0,576 \\
\hline $17 \mathrm{mo}$ & 3,3 & 3,4 & 3,2 & 3,5 & 0,1 & 0,326 & 0,128 & 0,784 \\
\hline \multicolumn{9}{|l|}{ PS (cm) } \\
\hline $14 \mathrm{mo}$ & 17,6 & 17,5 & 17,1 & 18 & 0,1 & 0,248 & $<0,001$ & 0,597 \\
\hline $17 \mathrm{mo}$ & 18,9 & 18,6 & 18,4 & 19,1 & 0,1 & 0,248 & $<0,001$ & 0,597 \\
\hline
\end{tabular}

et al., 1995), which may have balanced the growth between genetic groups in that period.
LEA is a cross-sectional measurement of the vertebral column of the animal, between 
the 12th and 13th ribs, in Musculus Longissimus thoracis, being indicative of the animal's degree of muscularity and also used to evaluate the yield of meat cuts of high commercial value by present a positive correlation with the weight of the main cuts of the carcass (Lopes et al., 2012).

The SFT was higher in the group supplemented with $\mathrm{CrP}$, compared to control heifers at 14 months, 2.1 and $1.6 \mathrm{~mm}$, respectively $(p=0.030)$. However, this difference was not maintained at 17 months ( $p>0.05)$, being the values of 3.3 and $3.4 \mathrm{~mm}$, for the animals supplemented with CrP and not supplemented, respectively. Different result was reported by Kneeskern et al. (2016), which evidenced the need to keep steers supplemented with CrP for longer time in finishing to reach the same degree of finish of the animals not supplemented with the mineral. There was no difference ( $p>$ 0.05) in the SFT between the genetic groups, although there was a difference in the FIN scores attributed to the carcasses of these animals. Ultrasonography is considered a good method for in vivo measurement of SFT (Andriguetto et al., 2009; Andriguetto et al., 2011) and the cause of divergence between the variables can be attributed to the removal of the leather during the slaughter flow, altering the amount of fatty tissue (Tarouco et al., 2005; Polizel Neto et al., 2009b).

CrP did not promote a difference ( $p>$ 0.05) in the CP growth at 14 and 17 months, however, in relation to the genetic group, RGN heifers presented higher CP than the NEL heifers $(18.0 \mathrm{~cm}$ and $17,1 \mathrm{~cm}$ at 14 months, $19.1 \mathrm{~cm}$ and $18.4 \mathrm{~cm}$ at 17 months, respectively, $\mathrm{p}<0.001$ ).

It was confirmed that RGN animals have a larger bone structure, inherent to the genotype, but there was no negative interference in WCY, which was higher in these animals, as already discussed.

\section{Conclusion}

Supplementation with CrP did not influence the productive performance and carcass characteristics of Nellore and Fl Rubia Gallega x Nellore heifers raised to pasture.

The use of the Rubia Gallega genotype in Nellore heifers provides an increase in performance parameters related to weight gain and subsidizes the production of heavier carcasses, with lower fat percentages and higher yields, when compared to the use of Nellore heifers.

\section{References}

Andriguetto, A.; Jorge, A.M.; Cervieri, R.C.; Cucki T.O.; Rodrigues E.; Arrigoni M.B. 2009. Relação entre medidas ultrassônicas e da carcaça de bubalinos Murrah abatidos em diferentes períodos de confinamento. Revista Brasileira de Zootecnia, 38: 1762-1768.

Andrighetto, C.; Soares Filho, C.V.; Foncesca, R.; Caminhas, M.M.T.; Perri, S.H.V. 2011. Correlações entre escores visuais e características produtivas em prova de ganho de peso de bovinos da raça Nelore Mocha. Veterinária e Zootecnia, 18: 602609.

Bernhard, B.C.; Burdick, N.C.; Rathmann, R.J.; Carroll J. A.; Finck D. N.; Jennings M. A; Young T. R. and Johnson B. J. 2012. Chromium supplementation alters both glucose and lipid metabolismo in feedlot cattle during the receiving period. Journal of Animal Science, 90: 4857 - 4865.

Bianchini, W.; Silveira, A.C.; Arrigoni, M.B. 2008. Crescimento e características de carcaça de bovinos superprecoces Nelore, Simental e mestiços. Revista Brasileira de Saúde e Produção Animal, 9: 554-564.

Climaco, S.M.; Ribeiro, E.L.A.; Mizubuti, I.Y.; Silva, L.D.F.; Freitas Barbosa, M.A.A.; Bridi, A.M. 2011. Desempenho e características de carcaça de bovinos de corte de quatro grupos genéticos terminados em confinamento. Revista Brasileira de Zootecnia, 40: 1562-1567.

Domínguez-Vara, I.A.; González-Muñoz, S.S.; Pinos-Rodríguez, J.M.; Bórquez-Gasteluma, J.L.; Bárcena-Gamab, R.; Mendoza-Martíneze, G.; Zapataf, L.E; Landois-Palenciag L.L. 2009. Effects of feeding selenium-yeast and chromium-yeast to finishing lambs on growth, carcass characteristics, and blood hormones and metabolites. Animal Feed Science and Technology, 152: 42-49.

Ewelina K, Krejpcio Z. 2010. Chromium(III) propionate complex supplementation improves carbohydrate metabolism in insulin-resistance rat model. Food and Chemical Toxicology. 8: 27912796.

Felício, P.E. Fatores que Influenciam na Qualidade da Carne Bovina. 1997. In: A. M. Peixoto; J. C. Moura; V.P. de Faria. (Org). Produção de Novilho de Corte. 1.ed. Piracicaba: FEALQ, 79-97. 
FERRAZ, J. B. S.; FELÍCIO, P. E. 2010. Production systems - An example from Brazil. Meat Science, 84: 238-243.

Grasso, F.; Rosa, G.; Bordi, A. 2001. Effect of space allowance and chromium supplementation on buffalo. Zootécnica e Nutrizione Animale, 27: 5563.

Kneeskern, S.G.; Dilger, A.C.; Loerch, S.C.; Shike, D.W; Felix, T.L. 2016. Effects of chromium supplementation to feedlot steers on growth performance, insulin sensitivity, and carcass characteristics. Journal of Animal Science, 94: 217-226.

Kuss, F.; Restle, J.; Brondani, I.L. Pacheco P.S.; Silveira, M.F.; Pazdiora, R.D.; Cezimbra, I.M. 2007. Órgãos vitais e trato gastrintestinal de vacas de descarte mestiças Charolês x Nelore abatidas com pesos distintos. Revista Brasileira de Zootecnia, 36: 421-429.

Lopes, J.S.; Rorato, P.R.N.; Weber, T.; Rodrigues, R.D; Comin, J.G.; Dornelles, M.A. 2008. Metanálise para características de carcaça de bovinos de diferentes grupos genéticos. Ciência Rural, 38: 2278-2284.

Lopes, L.S.; Ladeira, M.M.; Paulino, P.V.R; Mário Luiz Chizzotti, M.L.; Ramos, E.M.; Oliveira, D.M. 2012. Características de carcaça e cortes comerciais de tourinhos Red Norte e Nelore terminados em confinamento. Revista Brasileira de Zootecnia, 41: 970-977.

Menezes, L.F.G.; Restle, J. 2005. Desempenho de novilhos de gerações avançadas do cruzamento alternado entre as raças Charolês e Nelore, terminados em confinamento. Revista Brasileira de Zootecnia, 34: 1927-1937.

Menezes, L.F.G.; Restle, J.; Brondani, I.L.; Kuss, F.; Alves Filho, D.C.; Silveira, M.F.; Leite, D.T. 2007. Órgãos internos e trato gastrintestinal de novilhos de gerações avançadas de cruzamento rotativo entre as raças Charolês e Nelore terminados em confinamento. Revista Brasileira de Zootecnia, 36: 120-129.

Missio, R.L.; Restle, J.; Moletta, J.L.; Kuss, F.; Neiva, J.N.M; Moura, I.C.F. 2013. Características de carcaça de vacas de descarte abatidas com diferentes pesos. Revista Ciência Agronômica, 44: 644-651.

Montemór, C.H.; Marçal, W.S. 2009. Desempenho de bovinos da raça nelore suplementados com cromo orgânico. Semina: Ciências Agrárias, 30: 701-708.

Moreira, P.S.A; Lourenço, F.J.; Polizel Neto, A.; Heirinch, L.C.; Berber, R.C.A. 2012. Quelato de cromo em suplementos minerais para bovinos de corte. Comunicata Scientiae, 3: 186-191.
Oliete, B.; Moreno, T.; Carballo, J.A.; Monserrat L.; Sánchez, L. 2006. Estúdio de la calidad de la carne de ternera de raza Rubia Gallega a lo largo de la maduración al vacio. Archivos de Zootecnia, 55: 3-14.

Oliveira, E.R.; Castro, F.G.F.; Gandra, J.R.; Ramos, R.C.; Brandstetter, E.V.; Monção, F.P.; Moura, L.V.; Rodrigues, G.C.G.; Lemos, T. 2016. Effect of organic sources of chromium supplementation with low levels of protein on the growth performance and rumen fermentation profile of growing steers. Journal of Animal and Plant Sciences, 26: 347-354.

Ottersbach, R.A., Santos, R. e Germano, R.M. 2008. Variações de cortisol sérico em bovinos de corte (Bos taurus indicus) Nelore e (Bos taurus indicus x Bos taurus taurus) cruzamento industrial, durante o processo de abate. PUBVET, 2 (42): $1-11$.

Owens, F.N.; Dubeski, P.; Hanson, C.F. 1993. Factors that alter the growth and development of ruminants. Journal of Animal Science, 71:31383150.

Owens, F.N.; Gill, D.R.; Secrist, D.S.; Coleman S.W. 1995. Review of some aspects of growth and development of feedlot cattle. Journal of Animal Science, 73(12): 3152-3172.

Polizel Neto, A.; Jorge, A.M.; Moreira, P.S.A.; Gomes, H.F.G.; Pinheiro, R.S.B. 2009a. Desempenho e qualidade da carne de bovinos Nelore e Fl Brangus $x$ Nelore recebendo suplemento com cromo complexado à molécula orgânica na terminação a pasto. Revista Brasileira de Zootecnia, 38: 737-745.

Polizel Neto, A.; Jorge, A.M.; Moreira, P.S.A.; Gomes, H.F.G.; Pinheiro, R.S.B.; Andrade, E.N. 2009b. Correlações entre medidas ultrasônicas e na carcaça de bovinos terminados em pastagem. Revista Brasileira de Saúde e Produção Animal, 10: 137-145.

Rubiano, G.A.; Arrigoni, M.B.; Martins, C.L.; Rodrigues, E.; Gonçalves, E.C.; Angerami, C.N. 2009. Desempenho, características de carcaça e qualidade da carne de bovinos superprecoces das raças Canchim, Nelore e seus mestiços. Revista Brasileira de Zootecnia, 38: 2490-2498.

Sanchez, L.; Becerra, J.J; Iglesias, A.; Monserrat, L. 2005. Valoración del crecimiento em animales cruzados de Rubia Gallega com Nelore. Archivos de Zootecnia, 54: 497-500.

Santos, M.E.R.; Fonseca, D.M.; Euclides, V.P.B. 2009. Produção de bovinos em pastagens de capim-braquiária diferidas. Revista Brasileira de Zootecnia, 38: 635-642.

Spears, J.W.; Weiss, W.P. 2014. Invited Review: 
Mineral and vitamin nutrition in ruminants. Professional Animal Scientist, 30: 180-191.

Swanson, K.C.; Harmon, D.L.; Jacques, K.A.; Larsona, B.T.; Richards C.J.; Bohnert, D.W; Patona S.J. 2000. Efficacy of chromium-yeast supplementation for growing beef steers. Animal Feed Science and Technology, 86: 95-105.

Tarouco, J.U.; Lobato, J.F.P.; Tarouco, A.K.; Massia, G.S. 2005. Relação entre medidas ultrasônicas e espessura de gordura subcutânea ou área de olho-de-lombo na carcaça em bovinos de corte. Revista Brasileira de Zootecnia, 34: 2074-2084.

Taveira, R.Z.; Silveira Neto, O.J.; Amaral, A.G.; Luz, T.N; e Brito Júnior, V.A. 2014. Comparação de desempenho de bovinos Nelore e mestiços Nelore-Rubia Gallega em sistema de confinamento. PUBVET, 8: 243-255.

Varela, A.; Oliete, B.; Moreno, T.; Portela, C.; Monserrat, L.; Carballo, J.A.; Sanchez, L. 2004. Effect of pasture finishing on the meat characteristics and intramuscular fatty acid profile of steers of the Rubia Gallega breed. Meat Science, 67: 515-522.

VAZ,F.N.; Restle,J; Arboite,M.Z.; Pascoal, L.P.: Pacheco, R.F. 2010. Características de carcaça e da carne de novilhos e novilhas braford superjovens, terminados com suplementação em pastagem cultivada. Ciência Animal Brasileira, 11 (1): 42-52.

Zanetti, M.A.; Salles, M.S.V.; Brisola, M.L.; Cesar, M.C. 2003. Desempenho e resposta metabólica de bezerros recebendo dietas suplementadas com cromo. Revista Brasileira de Zootecnia, 32: 532-1535. 